\title{
Correction to: Rotator Cuff
}

\author{
Eva Llopis, Alexeys Perez, and Luis Cerezal
}

Correction to: J. Hodler et al. (eds.), Musculoskeletal Diseases 2021-2024, IDKD Springer Series,

https://doi.org/10.1007/978-3-030-71281-5_2

\section{Corrections:}

The original version of the chapter was inadvertently published with incorrect Surname and Given name in reference 18 as sj L. This has been corrected as "Choo HJ, SJ Lee, Kim JH, et al. Delaminated tears of the rotator cuff: prevalence, characteristics, and diagnostic accuracy using indirect MR arthrography. Am J Roentgenol. 2015;204:360-6." 
Open Access This chapter is licensed under the terms of the Creative Commons Attribution 4.0 International License (http://creativecommons. org/licenses/by/4.0/), which permits use, sharing, adaptation, distribution and reproduction in any medium or format, as long as you give appropriate credit to the original author(s) and the source, provide a link to the Creative Commons license and indicate if changes were made.

The images or other third party material in this chapter are included in the chapter's Creative Commons license, unless indicated otherwise in a credit line to the material. If material is not included in the chapter's Creative Commons license and your intended use is not permitted by statutory regulation or exceeds the permitted use, you will need to obtain permission directly from the copyright holder. 